\title{
Diabetic Retinopathy and Maculopathy
}

\author{
Authors \\ Hans-Peter Hammes ${ }^{1}$, Klaus Dieter Lemmen², Bernd Bertram ${ }^{3}$
}

\author{
Affiliations \\ $15^{\text {th }}$ Medical Department, Medical Faculty Mannheim, \\ University of Heidelberg \\ 2 Ophthalmological practice, Düsseldorf \\ 3 Ophthalmological practice, Aachen \\ published online 17.12 .2020 \\ Bibliography \\ Exp Clin Endocrinol Diabetes 2021; 129: S64-S69 \\ DOI 10.1055/a-1284-6223 \\ ISSN $0947-7349$ \\ (c) 2020. Thieme. All rights reserved. \\ Georg Thieme Verlag KG, Rüdigerstraße 14, \\ 70469 Stuttgart, Germany
}

German Diabetes Association: Clinical Practice Guidelines This is a translation of the DDG clinical practice guideline published in Diabetologie 2020; 15: S175-S180, DOI 10.1055/a-1194-1638

\section{Correspondence}

PD Dr. Klaus Dieter Lemmen

Ophthalmological practice Drs. Lemmen \& Vahdat

Blumenstraße 28

40212 Düsseldorf

Deutschland

kdlemmen@t-online.de

\section{Epidemiology}

Diabetic retinopathy is a common microvascular complication of diabetes mellitus.

\section{People with Type 1 Diabetes}

- Retinopathy is rare in children before puberty.

- The prevalence of diabetic retinopathy disease is $24-27 \%$ in people with type 1 diabetes.

- Clinically significant macular edema can occur in up to $10 \%$ of people with type 1 diabetes.

\section{People with Type 2 Diabetes}

- At the time of diagnosis, $2-16 \%$ of patients already have retinopathy.

- Retinopathy can be detected in $9-16 \%$ of patients.

- Diabetic maculopathy can occur in $6 \%$ of patients.

\section{Symptoms}

Diabetic retinopathy and maculopathy have long been asymptomatic. Therefore, regular ophthalmological control intervals must be observed even without deterioration of vision.

Warning signs that indicate retinal complications include:

- Sudden changes in visual acuity or

- Uncorrectable visual deterioration.
If the macula is affected:

- Reading difficulties up to the loss of the ability to read,

- Color sense disorders,

- General visual deterioration in the sense of blurred vision,

- "Floaters" in front of the eye caused by vitreous hemorrhages up to practical blindness due to persistent vitreous hemorrhages or in case of tractive retinal detachments.

\section{Risk Factors}

- Diabetes duration

- Hyperglycemia

- Arterial hypertension

- Nephropathy

- Hormonal changes (pregnancy, puberty)

- Smoking (for type 1 diabetes)

- Male

\section{Particularity}

Euglycemic reentry (early worsening) of retinopathy affects patients with type 1 and type 2 diabetes. It is rare ( $<5 \%$ of patients), occurs mainly within the first 12 months of metabolic improvement, is more frequent in patients with long-term diabetes (> 10 years) and longterm poorly-controlled blood glucose (HbA1c>10\%). However, the most important factor is a pre-existing retinopathy, regardless of its degree. It is not prevented by a gradual improvement of HbA1c. In the long run, the positive effect of blood glucose improvement prevails in patients with type 1 diabetes. 


\section{Diagnostics}

The following must be examined:

- Visual acuity,

- Anterior segment of the eye,

- Ocular fundus with binocular-biomicroscopic fundoscopy (with dilated pupil),

- Eye pressure in severe non-proliferative or proliferative retinopathy, in neovascularization of the iris,

- Optical coherence tomography (OCT) optional for the differential diagnosis of maculopathy, or obligatory in case of diabetic maculopathy requiring therapy,

- Fluorescein angiography in certain constellations of advanced diabetic retinopathy or maculopathy.

The findings are sent to the family doctor/diabetologist on the documentation form "Ophthalmologic notification" (see - Fig. 1).

\section{PRACTICE TOOL (APPENDIX)}

- Fig. 1: Documentation form for the general practitioner/ diabetological to communicate with the ophthalmologist

- Fig. 2: Documentation form for the ophthalmologic to communicate with the general practitioner / diabetologist. Download at: www.leitlinien.de/nvl/ diabetes/netzhautkomplikationen

- Fig. 3: Procedure for diabetes according to the National Health Care Guidelines for Diabetic Retinopathy and Maculopathy.

Diabetes health passport: https://eref.thieme.de/ZBNKV (only available in german)

\section{Treatment Objectives}

Avoiding visual loss and blindness through interdisciplinary cooperation with:

- Near-normal blood glucose control (see DDG Guidelines “Therapy of Type 1 Diabetes” and “Medical antihyperglycaemic treatment of diabetes mellitus type 2 "),

- Blood pressure normalization (see DDG Guideline “Management of hypertension in patients with diabetes mellitus") and

- Ophthalmological therapy.

\section{PRACTICE TOOL (APPENDIX)}

- Tab. 1: Stage classification, ophthalmological findings and therapy

\section{Times of Examination}

\section{Fundamental}

- If no retinopathy or general risk factors are present, examination by the ophthalmologist every 2 years. The general risk factors should have been communicated to the ophthalmologist in advance on the documentation form "General practitioner/diabetological communication to the ophthalmologist" ( $>$ Fig. 1).

- If there is no retinopathy and one or more general risk factors are present or the ophthalmologist is not aware of the general risk factors: examination by the ophthalmologist once a year.

- If retinopathy is already present: control intervals according to the ophthalmologist's instructions.

\section{Exceptions to the Rule}

- Children below the age of 11 must be examined only if the diabetes has been present for 5 years.

- Pregnant women: immediately upon detection of pregnancy, then every 3 months. If a retinopathy develops or progresses during pregnancy, the ophthalmologist determines the intervals.

- Patients with type 2 diabetes: immediately upon detection of the disease.

- Before planned and after rapid and significant blood glucose reduction, all patients must be monitored by an ophthalmologist at short notice (risk of temporary worsening of retinopathy), especially if retinopathy is known to be present.

- Intensification of therapy with insulin (continuous subcutaneous insulin infusion [CSII], intensified conventional therapy [ICT]) and with glucagon-like peptide-1 (GLP-1)-receptor agonists should be accompanied by careful medical attention to monitor retinopathy worsening.

\section{Addresses on the Internet}

- Website of the German Diabetes Society (Deutsche Diabetes Gesellschaft): www.deutsche-diabetes-gesellschaft.de

- Website of the Initiative Group Early Diagnosis of Diabetic Eye Diseases (IFDA) and the Working Group Diabetes and Eye (AGDA) (Initiativgruppe Früherkennung diabetischer Augenerkrankungen (IFDA) und der Arbeitsgemeinschaft Diabetes und Auge (AGDA)):

www.diabetes-auge.de

- Information on the topic of diabetic eye diseases by the Professional Association of Ophthalmologists in Germany: http://cms.augeninfo.de/fileadmin/pat_brosch/diabetes.pdf

- Information from the Medical Center for Quality in Medicine (ÄZQ) (Ärztlichen Zentrums für Qualität in der Medizin (ÄZQ)); Berlin: National Healthcare Guideline (Nationale Versorgungsleitlinie). Prevention and therapy of retinal complications in diabetes (Prävention und Therapie von Netzhautkomplikationen bei Diabetes).( $>$ Fig. 2,3) Long version 2nd edition 2015 at: www.versorgungsleitlinien.de 


\begin{tabular}{|c|c|c|}
\hline \multicolumn{3}{|c|}{ Health insurance company or cost unit } \\
\hline \multicolumn{3}{|c|}{ Name, first name of the insured person } \\
\hline Health insurance company no. & Insured person no. & Status \\
\hline Branch no. & Physician no. & Date \\
\hline
\end{tabular}

General practitioner/diabetological communication to the ophthalmologist

The risk of retinal complications in diabetes consists of

- The general risk assessed by the general practitioner/diabetologist and

- The ophthalmological risk, which is assessed by the ophthalmologist.

In this communication, the general practitioner/diabetologist gives the assessment of the general risk. The overall risk can only be assessed after the examination by the ophthalmologist.

\begin{tabular}{|c|c|c|}
\hline Diabetes type: & $\begin{array}{l}\square \text { Type } 1 \text { diabe } \\
\square \text { Type } 2 \text { diabe }\end{array}$ & \\
\hline Diabetes known since: & ...............Years & (limit value*:> 10 years) \\
\hline HbA1c: & $\ldots \ldots \ldots \ldots$ & (limit value*: > $7.5 \%$ ) \\
\hline Representative blood pressure value: & ............mmHg & (limit value*: $>140 / 85 \mathrm{mmHg}$ ) \\
\hline Existing vascular complications, especially kidney: & $\begin{array}{l}\square \text { Yes } \\
\square \text { No }\end{array}$ & \\
\hline $\begin{array}{l}\text { Integrative assessment }{ }^{*} \text { of the general risk based } \\
\text { on the risk factors listed above and the overall } \\
\text { assessment of the patient }\end{array}$ & $\begin{array}{l}\square \text { Rather low ris } \\
\square \text { Rather increa }\end{array}$ & \\
\hline
\end{tabular}

${ }^{*}$ The values given are limit values for an increased risk. Since minimally exceeding individual limit value does not result in a large risk increase, an integrative assessment of all risk factors must always be made together.

Further general practitioner/diabetological diagnoses/remarks:

The retinal examination requires a dilation of the pupil with medication so that no vehicle can be driven for two to four hours afterwards.

- Fig. 1 Documentation form for the general practitioner/diabetological communication to the ophthalmologist (Dokumentationsbogen für die hausärztliche/diabetologische Mitteilung an den Augenarzt). Source: German Medical Association (Bundesärztekammer - BÄK), National Association of Statutory Health Insurance Physicians (Kassenärztliche Bundesvereinigung - KBV), Association of Scientific Medical Societies (Arbeitsgemeinschaft der Wissenschaftlichen Medizinischen Fachgesellschaften - AWMF). National Healthcare Guideline Prevention and Treatment of Retinal Complications in Diabetes Long Form (Nationale Versorgungs- Leitlinie Prävention und Therapie von Netzhautkomplikationen bei Diabetes-Langfassung), 2nd Edition. Version 2. 2015. www.netzhautkomplikationen. versorgungsleitlinien.de; DOI: 10.6101/AZQ/000318. [rerif] 


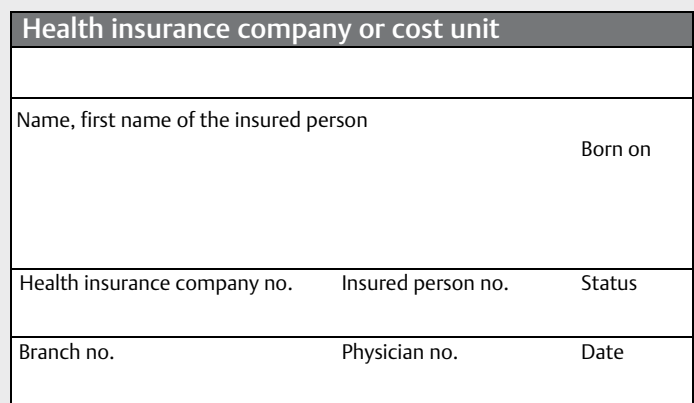

Ophthalmologist notification

The ocular fundus should be examined with a dilated pupil.

Anterior sections: Rubeosis iridis

Retinopathy stage:

No diabetic retinopathy

Mild or moderate diabetic retinopathy

Severe non-proliferative diabetic retinopathy

Proliferative diabetic retinopathy

Clinically-significant diabetic macular edema

Findings compared to the preliminary examination:

Stable

Improved

Worsened

Preliminary examination findings not known

Procedure:

OCT

Fluorescein angiography

Panretinal photocoagulation

Focal photocoagulation at posterior pole of eye

Intravitreal drug administration

Vitrectomy

Best corrected distance vision:

Other ophthalmologic diagnoses/remarks:

$\begin{array}{cc}\text { Right } & \text { Left } \\ \text { eye } & \text { eye }\end{array}$

\section{Control examination for diabetic retinopathy:}

In 2 years

In 1 year

$\square \ln$...... months

Date of examination, signature and stamp of the ophthalmologist

- Fig. 2 Documentation form for the ophthalmologic communication to the general practitioner/diabetologist (Dokumentationsbogen für die augenfachärztliche Mitteilung an den Hausarzt/Diabetologen). Source: German Medical Association (Bundesärztekammer - BÄK), National Association of Statutory Health Insurance Physicians (Kassenärztliche Bundesvereinigung - KBV), Association of Scientific Medical Societies (Arbeitsgemeinschaft der Wissenschaftlichen Medizinischen Fachgesellschaften - AWMF). National Healthcare Guideline Prevention and Treatment of Retinal Complications in Diabetes Long Form (Nationale Versorgungs- Leitlinie Prävention und Therapie von Netzhautkomplikationen bei Diabetes-Langfassung), 2nd Edition. Version 2. 2015. www.netzhautkomplikationen. versorgungsleitlinien.de; DOI: 10.6101/AZQ/000318. [rerif] 
- Table 1 Stage classification, ophthalmological findings and therapy for retinopathy and maculopathy.

\begin{tabular}{|c|c|c|}
\hline Stage & Ophthalmological findings & Ophthalmological therapy \\
\hline \multicolumn{3}{|c|}{ 1.1 Non-proliferative diabetic retinopathy } \\
\hline Mild & Microaneurysms & No photocoagulation \\
\hline Moderate & $\begin{array}{l}\text { Additionally, individual intraretinal bleeding, venous beading (venous } \\
\text { caliber fluctuations) }\end{array}$ & No photocoagulation \\
\hline Severe & $\begin{array}{l}\text { " } 4-2-1 \text { rule" }>20 \text { individual microaneurysms, intraretinal bleeding in } \\
4 \text { quadrants or venous beading in } 2 \text { quadrants or intraretinal } \\
\text { microvascular anomalies (IRMA) in } 1 \text { quadrant }\end{array}$ & Photocoagulation only for risk patients \\
\hline \multicolumn{3}{|c|}{1.2 Proliferative diabetic retinopathy } \\
\hline & Proliferation of papilledema, proliferation not close to the papilla & $\begin{array}{l}\text { Photocoagulation, only in selected cases } \\
\text { intravitreal surgical drug administration (IVOM) }\end{array}$ \\
\hline & Vitreous hemorrhage retinal detachment & $\begin{array}{l}\text { Photocoagulation, if possible; otherwise possibly } \\
\text { vitrectomy }\end{array}$ \\
\hline \multicolumn{3}{|c|}{ 2. Diabetic maculopathy } \\
\hline \multirow[t]{4}{*}{$\begin{array}{l}\text { 2.1 Diabetic macular } \\
\text { edema }\end{array}$} & $\begin{array}{l}\text { Spot/fleck-like zone(s) of edema, intraretinal bleeding or hard } \\
\text { exudates at the posterior pole }\end{array}$ & No photocoagulation \\
\hline & Visually threatening if close to macula = clinically significant & \\
\hline & - Fovea not included & Targeted photocoagulation \\
\hline & - Fovea included & $\begin{array}{l}\text { Intravitreal surgical drug delivery, optionally } \\
\text { targeted laser coagulation }\end{array}$ \\
\hline $\begin{array}{l}2.2 \text { Ischemic } \\
\text { maculopathy }\end{array}$ & $\begin{array}{l}\text { Diagnosis by fluorescein angiography: occlusion of the perifoveal } \\
\text { capillary network }\end{array}$ & No therapy possible \\
\hline
\end{tabular}




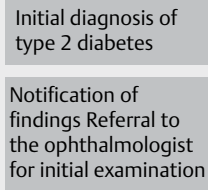

\section{Known type 2} diabetes

\section{Notification of}

findings Referral to

the ophthalmologist

(at least $1 \times$ yearly)

(at least $1 \times$ yearly)
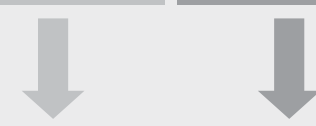

Standardized ophthalmological examination

No retinal disease

detected

- No general risk factors,

General

practitioner/diabetological

communication to the

ophthalmologist

documentation form

present: follow-up again in

2 years

- 1 or more general risk factors

or general risk factors known,

General

practitioner/diabetological

communication to the

ophthalmologist

documentation form not

present: follow-up again in

1 year

Continuous monitoring and

management of diabetes

therapy

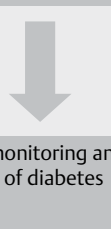

Fig. 3 Procedure for type 2 diabetes according to the National Healthcare Guidelines for Diabetic Retinopathy and Maculopathy [3]. [rerif]

\section{Conflict of interest}

K. D. Lemmen: Lecture fees: Bayer, Novartis, Advisory Board, Pharm-Allergan. H.-P. Hammes: Lecture fees: Novartis, Bayer, MSD, Novo Nordisk, Boehringer Ingelheim, Sanofi. B. Bertram: no conflict of interest.

\section{References}

[1] Programm für Nationale VersorgungsLeitlinien. Träger: Bundesärztekammer, Kassenärztliche Bundesvereinigung, Arbeitsgemeinschaft der Wissenschaftlichen Medizinischen Fachgesellschaften. Nationale VersorgungsLeitlinie: Prävention und Therapie von Netzhautkomplikationen bei Diabetes. Langfassung. 2015; 2. Aufl. Version 1. AWMFRegister-Nr.: nvl-001b

[2] Schorr S, Hammes HP, Müller UA et al. Nationale Versorgungsleitlinie. Prävention und Therapie von Netzhautkomplikationen. Deutsches Ärzteblatt. 2016; (im Druck)

[3] Ziemssen F, Lemmen K, Bertram B et al. Nationale Versorgungsleitlinie (NVL). Diabetische Retinopathie - 2. Auflage der NVL zur Therapie der diabetischen Retinopathie. Ophthalmologe 2016; 113: 623-638

[4] Bertram B, Lemmen KD, Agostini J et al. Netzhautkomplikationen bei Diabetes. Der Diabetologe 2016; 12: 509-52 